\title{
The safety of prolong usage of diazepam on liver and renal functions in rats
}

\author{
Wajdy Jabbar Majid ${ }^{1, *}$ and Tayseer Ali Talab ${ }^{2}$ \\ ${ }^{1}$ Department of Biochemistry, Thi-Qar Medical College, University of Thi- Qar, Iraq. \\ 2 Department of Pharmacology, Thi-Qar Medical, University of Thi- Qar, Iraq.
}

International Journal of Biological and Pharmaceutical Sciences Archive, 2021, 02(01), 059-061

Publication history: Received on 02 July 2021; revised on 02 August 2021; accepted on 04 August 2021

Article DOI: https://doi.org/10.53771/ijbpsa.2021.2.1.0069

\begin{abstract}
In this study the effect of diazepam on some blood chemistry values was studied in male rats. Intraperitoneal administration of diazepam at a dose of $0.6 \mathrm{mg} / \mathrm{kg}$ body weight for 60 days didn't induce significant changes in serum glucose, urea, cholesterol, aspartate aminotransferase (AST), alanine aminotransferase (ALT), total bilirubin, creatinine and alkaline phosphatase levels. Findings of this study give further sound for the safety of benzodiazepines.
\end{abstract}

Keywords: Diazepam; Safety; Liver, Kidney; Blood chemical values

\section{Introduction}

Diazepam (a benzodiazepine) was widely used in medical practice as antiepileptic, hypnotic, centrally acting muscle relaxant, tranquilizer and in treatment of alcohol withdrawal reaction [1]. Many unwanted effects were associated with benzodiazepine therapy including drowsiness, ataxia, hypotension, blurred vision, incontinence and respiratory depression [2], and other unusual responses were also recorded with benzodiazepines therapy including, nightmares, paradoxical delirium, confusion, depression, aggression and hostile behavior [3]. Hegarty and Dundee reported a significant incidence of painless thrombosis at injection site 7 to 10 days after intravenous diazepam administration, hematological, renal and hepatic toxicity have seldom been reported for benzodiazepines [3-5], however, a case of acute hepatic necrosis in doubtful relation to diazepam in-combination with other drugs has been recorded [6].

\section{Material and methods}

Twenty mature albino male rats from the colony of scientific research council, 12-14 weeks old, with a body weight of 250-300g were used. The animals were housed in individual cages and kept in a temperature-controlled room $\left(22 \pm 1^{\circ} \mathrm{C}\right)$ with photo period of $14 \mathrm{hr}$. light and $10 \mathrm{hr}$. darkness. Water and pelleted diet were provided ad libitum. After seven days of adaptation, rats were randomly divided into two equal groups. The first group was injected intraperitoneally with $0.6 \mathrm{mg} / \mathrm{kg}$ body weight of diazepam (Gewacalm ${ }^{\mathrm{R}}$, Chemicalinz, AG-Austria) daily in a single dose for 60 days. Control animals were treated with normal saline. On the morning of day 61 post-treatment, blood was collected by cardiac puncture (without anesthesia) and allowed to stand for $4 \mathrm{hr}$. at refrigerator temperature $\left(4^{\circ} \mathrm{C}\right)$ before centrifugation at 2500RPM for 30 minutes and the prepared sera were stored in deep freezer $\left(-20^{\circ} \mathrm{C}\right)$. Glucose, urea, total bilirubin, cholesterol, creatinine, alkaline phosphatase, AST, ALT was determined with the technicon SM A 12/60 system (Technicon Co., Domont, France). The difference between control and treated group was detected by student t-test [7].

\footnotetext{
${ }^{*}$ Corresponding author: Wajdy Jabbar Majid

Department of Biochemistry, Thi Qar Medical College, University of Thi- Qar,Iraq. 


\section{Results}

The study showed that intraperitoneal injection of diazepam to male rats at a dose of $0.6 \mathrm{mg} / \mathrm{kg}$ body weight daily for 60 days induced slight elevation in serum cholesterol, total bilirubin, creatinine and alkaline phosphatase levels, while the serum glucose, urea, ALT and AST levels were slightly decreased, however, all these effects were not significant (table 1).

Table 1 Blood chemistry values in male rats treated with $0.6 \mathrm{mg} / \mathrm{kg}$ bw of diazepam daily for 60 days

\begin{tabular}{|c|c|c|c|c|c|c|c|c|}
\hline Groups & $\begin{array}{c}\text { Glucose } \\
\mathbf{m g} / \mathbf{d l}\end{array}$ & $\begin{array}{c}\text { Urea } \\
\mathbf{m g} / \mathbf{d l} \mathbf{l}\end{array}$ & $\begin{array}{c}\text { Total } \\
\text { Cholesterol } \\
\mathbf{m g} / \mathbf{d l}\end{array}$ & $\begin{array}{c}\text { AST } \\
\mathbf{U} / \mathbf{l}\end{array}$ & $\begin{array}{c}\text { ALT } \\
\mathbf{U} / \mathbf{l}\end{array}$ & $\begin{array}{c}\text { Total } \\
\text { bilirubin } \\
\mathbf{m g} / \mathbf{d l}\end{array}$ & $\begin{array}{c}\text { Creatinine } \\
\mathbf{m g} / \mathbf{d l}\end{array}$ & $\begin{array}{c}\text { Alkaline } \\
\text { phosphatase } \\
\mathbf{m g} / \mathbf{d l}\end{array}$ \\
\hline Control & $112 \pm 15$ & $25 \pm 1.7$ & $64 \pm 5.5$ & $59.3 \pm 8.1$ & $15 \pm 1.1$ & $0.9 \pm 0.09$ & $0.67 \pm 0.06$ & $6.4 \pm 0.6$ \\
\hline $\begin{array}{c}\text { Diazepam } \\
\text { treated }\end{array}$ & $108 \pm 12$ & 26.2 .2 & $65 \pm 2.1$ & $55.4 \pm 9.8$ & $14 \pm 0.8$ & $1.0 \pm 0.13$ & $0.70 \pm 0.14$ & $6.8 \pm 0.8$ \\
\hline
\end{tabular}

\section{Discussion}

The liver is the most important organ in which drugs are structurally altered into metabolites, while kidneys in which drugs excreted, liver and kidneys received 20 and $25 \%$ of the cardiac output respectively, thus it is not surprising that drugs can damage these organs [8].

Biochemical tests have been used as indicators for the toxic effect of drugs and foreign substances on the liver, kidneys and other tissues [9].

Hepatic and renal toxicity and alteration of liver and renal function tests have been recorded with many central nervous system depressants [10], but there was no sound that diazepam induce hepatic or renal damage [3, 5]. Therefore, short acting benzodiazepines, such as oxazepam and lorazepam, have been said to be drug of choice for elderly patient or those with liver diseases [11].

Also, there were no previous reports showing that benzodiazepines affected macromolecules formation [12]. Otherwise, antiepileptic and hypnotic drugs are usually prescribed for long period, often in high dosage, and often in combination. It is hardly surprising, therefore that patients treated with these drugs showed evidence of highest degree of hepatic enzymes induction [13-15].

These enzymes are responsible for metabolism of drugs and endogenous substances [1-2]. Thus, the results of this study, in part, give further evidence to previous studies which showed that this enzyme system wasn't induced by diazepam [5]. In conclusion, the findings presented here give further sound for the safety of benzodiazepines previously prescribed $[1-2,11]$.

\section{Conclusion}

The findings of the current study revealed that diazepam (a benzodiazepine) for 60 days in rats didn't affect blood chemistry values especially liver and kidney parameters. These results give further sound for the safety of benzodiazepines.

\section{Compliance with ethical standards}

\section{Acknowledgments}

We acknowledged the dean of Thi-Qar College of medicine for the scientific support.

\section{Disclosure of conflict of interest}

The authors declare that there is no conflict of interest. 


\section{Statement of ethical approval}

The study was approved by the ethical committee of Thi-Qar College of medicine. It performed on animals according to the regulations of the ethical committee of Thi-Qar University.

\section{References}

[1] Goodman L, Gilman A. The pharmacological basis of therapeutic. The Macmillan Co. New York. 2005.

[2] Bowman WC, Rand MJ. Textbook of pharmacology. Black well Scientific Publications. 2010.

[3] Kalant H, Roschlan HE, Sellers EM. Principle of medical Pharmacology. Oxford University Press. 2015.

[4] Heqarty JE, Dundes JW. Sequelae after intravenous injection at three benzodiazepins-diazepam, lorazepam and flumittazepam. Brit Med J. 1977; 2:1384-1385.

[5] Schmid D. Benzodiazepines. In: Antiepileptic drug. Edited by DM Woodburg et a1. Raven Press. New York. 2002.

[6] Cuningham ML. Acute hepatic necrosis following treatment with amitriptyline and diazepam. Br J Psychiatry 1965; 111: 1107-1109.

[7] Duncan RC, Knapp RG, Clinton-Miller M. Experimental design and analysis of variance. In: Introductory biostatistics for the health sciences, 2nd ed. John Wiley and sons. New York. 1983.

[8] Laurence DR, Bennett PN. Clinical pharmacology. Churchill Livingstone. 1987.

[9] Walmsley RN, White GH. Pocket diagnostic clinical chemistry. Blackwell Scientific Publications. 1985.

[10] Herfindal ET, Hirschman JL. Clinical pharmacy and therapeutics. The William Sandwilkins Co. Baltimore. 1995.

[11] Al-Tahan FJ, Al- Janabi AS and Al-Snafi AE. Effect of chronic diazepam treatment on fertility and sexual ability of male rats. Dirasat. 1993; 20(4): 151-158.

[12] Al-Snafi AE, Kubba MA, Al-Tahan FJ, Al-Janabi AS. Effect of chronic diazepam treatment on the reproductive performance of male rats. Iraqi J Biol Science. 1993;11: 82-92.

[13] Al- Tahan FJ, Al-Janabi, AS. and Al-Snafi AE. The effect of chronic diazepam treatment in rats on fetal and pup characteristics. Iraqi J Biol Science. 1995; 14:76-80.

[14] A bdul-baqi A. Effect of phenobarbitone and methagualone on some hepatic microsomal enzymes in Guinea pigs. Master thesis, College of Pharmacy. Baghdad University. 1978.

[15] Perucca E. Antiepileptic drug interactions. In: A textbook of epilepsy. Churchill-Livingstone, Edinburgh. 2001. 